\title{
First Records of Two Spirostomum Ciliates (Heterotrichea: Heterotrichida: Spirostomidae) from Korea
}

\author{
Seok Won Jang, Choon Bong Kwon, Mann Kyoon Shin* \\ Department of Biological Science, University of Ulsan, Ulsan 680-749, Korea
}

\begin{abstract}
Two Spirostomum species collected from freshwater in Korea were identified as S. caudatum (Müller, 1786) and S. teres (Claparède and Lachmann, 1858). They are recorded for the first time in Korea. The description was based on the observation of living specimens and protargol impregnated specimens. Diagnostics of these species are as follows. Spirostomum caudatum: body size $400-450 \times 20-30 \mu \mathrm{m}$ in vivo, shaped long and slender with a tapered posterior part, highly contractile; macronucleus ellipsoid; adoral zone of membranelles occupied 30\% of body length; somatic kineties 14-22 in number. Spirostomum teres: body size $240-460 \times 25-40 \mu \mathrm{m}$ in vivo, shaped long and slender with a flattened posterior end, highly contractile; cortical granules arranged in 2-3 rows; adoral zone of membranelles occupied 50\% of body length; somatic kineties 20-30 in number; macronucleus ellipsoid; micronuclei 2-3 in number. Spirostomum caudatum and S. teres are the most similar congeners, but they are different in the posterior part of body (tail-like posterior part vs. flattened posterior end), length of adoral zone of membranelles in body length (1/3 vs. 1/2), and the number of somatic kineties (14-22 vs. 20-30). These populations match with European populations in morphological characters.
\end{abstract}

Keywords: Spirostomum, morphology, redescription, taxonomy, freshwater, Korea

\section{INTRODUCTION}

The genus Spirostomum is assigned to the family Spirostomidae, order Heterotrichida, class Heterotrichea within the phylum Ciliophora. The family Spirostomidae is characterized by a highly contractile body, holotrichous somatic ciliation, long oral region in the anterior half and habitats in freshwater and brackish water. Within the family Spirostomidae four genera have been recognized until now (Lynn, 2008). The genus Spirostomum Ehrenberg, 1833 is differentially diagnosed by a long collecting canal in the contractile vacuole, a truncated posterior end and a long buccal field on the body edge (Curds et al., 1983). Since the establishment of the genus Spirostomum by Ehrenberg, 1833, nine species have been described worldwide (Claparède and Lachmann, 1858; Kahl, 1932; Shigenaka, 1959; Dragesco and DragescoKernéis, 1986; Foissner et al., 1992). In this study, two Spirostomum species were isolated and reported here for the first time in Korea. We provide morphological descriptions of two Spirostomum species for the study of Korean ciliate diversity.

\section{MATERIALS AND METHODS}

\section{Sample collection and culture}

Spirostomum caudatum was collected from a freshwater pond near the Simnidaebat (Bamboo Forest) located near the bank of the Taehwa River, Ulsan (35 $\left.32^{\prime} 55^{\prime \prime} \mathrm{N}, 129^{\circ} 18^{\prime} 40^{\prime \prime} \mathrm{E}\right)$, Korea on 9 March 2009. Spirostomum teres was collected from a freshwater pond in Gulhwa-ri, Beomseo-eup, Uljugun, Ulsan $\left(35^{\circ} 33^{\prime} 31^{\prime \prime} \mathrm{N}, 129^{\circ} 15^{\prime} 08^{\prime \prime} \mathrm{E}\right)$, Korea on 16 May 2011. The surface sediments $(\sim 10 \mathrm{~cm})$ including water were collected and transferred to Petri dishes with debris, then maintained in the laboratory for several days at room temperature. Meanwhile, a few wheat grains were added to the raw culture for the enrichment of the bacteria and ciliates ( $\mathrm{Li}$ et al., 2010).

\section{Morphological observation}

Cells were observed in vivo first using a dissecting microscope, and then with high magnification under an optical microscope $(\times 50-1,000)$. The infraciliature was revealed by
(C) This is an Open Access article distributed under the terms of the Creative Commons Attribution Non-Commercial License (http://creativecommons.org/ licenses/by-nc/3.0/) which permits unrestricted non-commercial use, distribution, and reproduction in any medium, provided the original work is properly cited. pISSN 2234-6953
*To whom correspondence should be addressed

Tel: 82-52-259-2396, Fax: 82-52-259-1694

E-mail: mkshin@ulsan.ac.kr 
protargol impregnations (Wilbert, 1975). Drawings of living cells were based on free-hand sketches, and those of the impregnated cells were made with a drawing device and photos. The classification and terminology are basically according to Lynn (2008).

\section{SYSTEMATIC ACCOUNTS}

Phylum Ciliophora Doflein, 1901

Subphylum Postciliodesmatophora Gerassimova and

Servin, 1976

Class Heterotrichea Stein, 1859

Order Heterotrichida Stein, 1859

Family Spirostomidae Stein, 1867

1*Genus Spirostomum Ehrenberg, 1833

2* Spirostomum caudatum (Müller, 1786) Delphy, 1939 (Tables 1, 2, Fig. 1)

Enchelis caudata Müller, 1786: 34.
Spirostomum filum Penard, 1922: 200; Dragesco and Dragesco-Kernéis, 1986: 375.

Spirostomum caudatum: Delphy, 1939: 144; Repak and Isquith, 1974: 328; Foissner et al., 1992: 324.

Diagnosis. Body size $400-450 \times 20-30 \mu \mathrm{m}$ in vivo; body shape cylindrical, slender with tail-like posterior end, ellipsoidal macronucleus, 13-18 somatic kineties, adoral zone about $30 \%$ of body length; and 48-56 adoral membranelles.

Description. Body size $400-450 \times 20-30 \mu \mathrm{m}$ in vivo. Body shape cylindrical, slender with tail-like posterior end, anterior end slightly beaked, length to width ratio about $17: 1$ (Fig. 1A, C), body fusiform when contracted (Fig. 1B, F). Macronucleus ellipsoidal, located near mid-body, size about $30 \times 20 \mu \mathrm{m}$ in vivo (Fig. 1A, B, F). Contractile vacuole located in tail-like posterior region (Fig. 1D). Body flexible. Cytoplasm colored slightly yellowish brown. Cortical granules arranged in 2-3 irregular rows between somatic kineties (Fig. $1 \mathrm{E})$. Movement relatively slow, usually gliding on the bottom. Somatic kineties arranged 13-18 longitudinally in impregna-

Table 1. Morphometrical characterization of Spirostomum caudatum (C) and S. teres (T)

\begin{tabular}{|c|c|c|c|c|c|c|c|c|c|c|}
\hline Characteristics & Species & Method & Mean & Med & Min & Max & SD & SE & CV & $\mathrm{n}$ \\
\hline \multirow[t]{4}{*}{ Body, length $(\mu \mathrm{m})$} & $\mathrm{C}$ & L & 409 & 400 & 400 & 450 & 17 & 5.13 & 4.16 & 11 \\
\hline & & S & 137 & 130 & 120 & 160 & 14.01 & 4.67 & 10.24 & 9 \\
\hline & $\mathrm{T}$ & L & 321 & 325 & 240 & 457 & 46.11 & 9.41 & 14.17 & 24 \\
\hline & & S & 192 & 191 & 157 & 237 & 23.73 & 5.59 & 12.43 & 18 \\
\hline \multirow[t]{4}{*}{ Body, width $(\mu \mathrm{m})$} & $\mathrm{C}$ & L & 25 & 20 & 20 & 30 & 5.22 & 1.57 & 21.28 & 11 \\
\hline & & S & 56 & 56 & 43 & 70 & 7.65 & 2.55 & 13.55 & 9 \\
\hline & $\mathrm{T}$ & L & 32 & 32 & 27 & 38 & 3.57 & 0.52 & 8.05 & 24 \\
\hline & & S & 89 & 90 & 73 & 109 & 11.90 & 2.80 & 13.17 & 18 \\
\hline \multirow[t]{2}{*}{ Body length/width, ratio } & $\mathrm{C}$ & L & 17 & 20 & 13 & 23 & 3.84 & 1.16 & 22.09 & 11 \\
\hline & $\mathrm{T}$ & L & 9.90 & 9.96 & 6.35 & 12.92 & 1.37 & 0.28 & 13.72 & 24 \\
\hline \multirow[t]{3}{*}{ Ma, length $(\mu \mathrm{m})$} & $\mathrm{C}$ & L & 30 & 30 & 30 & 35 & 1.51 & 0.45 & 4.95 & 11 \\
\hline & $\mathrm{T}$ & L & 41 & 41 & 40 & 52 & 4.94 & 1.59 & 14.35 & 14 \\
\hline & & S & 55 & 56 & 41 & 70 & 8.56 & 2.21 & 15.32 & 15 \\
\hline \multirow[t]{3}{*}{ Ma, width $(\mu \mathrm{m})$} & C & L & 20 & 20 & 18 & 21 & 0.70 & 0.21 & 3.52 & 11 \\
\hline & $\mathrm{T}$ & L & 13 & 13 & 10 & 16 & 2.12 & 0.57 & 16.57 & 14 \\
\hline & & S & 23 & 24 & 19 & 31 & 3.46 & 0.89 & 14.50 & 15 \\
\hline $\mathrm{Mi}$, diameter $(\mu \mathrm{m})$ & $\mathrm{T}$ & L & 3 & 3 & 3 & 5 & 0.43 & 0.09 & 13.80 & 22 \\
\hline Mi, number & $\mathrm{T}$ & L & 2 & 2 & 2 & 3 & 0.37 & 0.09 & 17.36 & 19 \\
\hline \multirow[t]{3}{*}{ AZM length/body length, ratio } & $\mathrm{C}$ & $\mathrm{L}$ & 0.31 & 0.33 & 0.28 & 0.35 & 2.10 & 0.63 & 6.69 & 11 \\
\hline & $\mathrm{T}$ & $\mathrm{L}$ & 0.43 & 0.43 & 0.40 & 0.49 & 0.03 & 0.01 & 5.94 & 20 \\
\hline & & $\mathrm{S}$ & 0.44 & 0.44 & 0.37 & 0.49 & 0.05 & 0.01 & 10.98 & 18 \\
\hline \multirow[t]{2}{*}{ Somatic kineties, number } & $\mathrm{C}$ & $\mathrm{S}$ & 15 & 15 & 13 & 18 & 1.72 & 0.70 & 11.61 & 6 \\
\hline & $\mathrm{T}$ & $\mathrm{S}$ & 23 & 24 & 20 & 30 & 2.94 & 0.78 & 12.23 & 14 \\
\hline \multirow[t]{2}{*}{ Adoral membranelles, number } & $\mathrm{C}$ & $\mathrm{S}$ & 54 & 54 & 48 & 56 & 3.59 & 1.27 & 6.70 & 8 \\
\hline & $\mathrm{T}$ & $\mathrm{S}$ & 87 & 86 & 80 & 92 & 3.74 & 1.00 & 4.32 & 14 \\
\hline \multirow[t]{2}{*}{ Dikinetids of undulating membrane, number } & $\mathrm{C}$ & $\mathrm{S}$ & 20 & 18 & 17 & 24 & 3.24 & 1.45 & 16.20 & 5 \\
\hline & $\mathrm{T}$ & $\mathrm{S}$ & 39 & 39 & 34 & 47 & 3.90 & 1.04 & 9.88 & 14 \\
\hline \multirow[t]{2}{*}{ Undulating membrane, length $(\mu \mathrm{m})$} & $\mathrm{C}$ & $\mathrm{S}$ & 14 & 15 & 10 & 17 & 2.61 & 1.17 & 18.11 & 5 \\
\hline & $\mathrm{T}$ & $S$ & 19 & 19 & 17 & 22 & 1.49 & 0.38 & 7.72 & 15 \\
\hline
\end{tabular}

Data are based on live ( $\mathrm{L}$ ) and impregnated specimens (S).

Mean, arithmetic mean; Med, median value; Min, minimum; Max, maximum; CV, coefficient of variation in \%; Ma, macronucleus; Mi, micronucleus (pl. micronuclei); AZM, adoral zone of membranelles.

Korean name: ${ }^{1 *}$ 나선입섬모충속, ${ }^{2 *}$ 꼬리나선입섬모충 

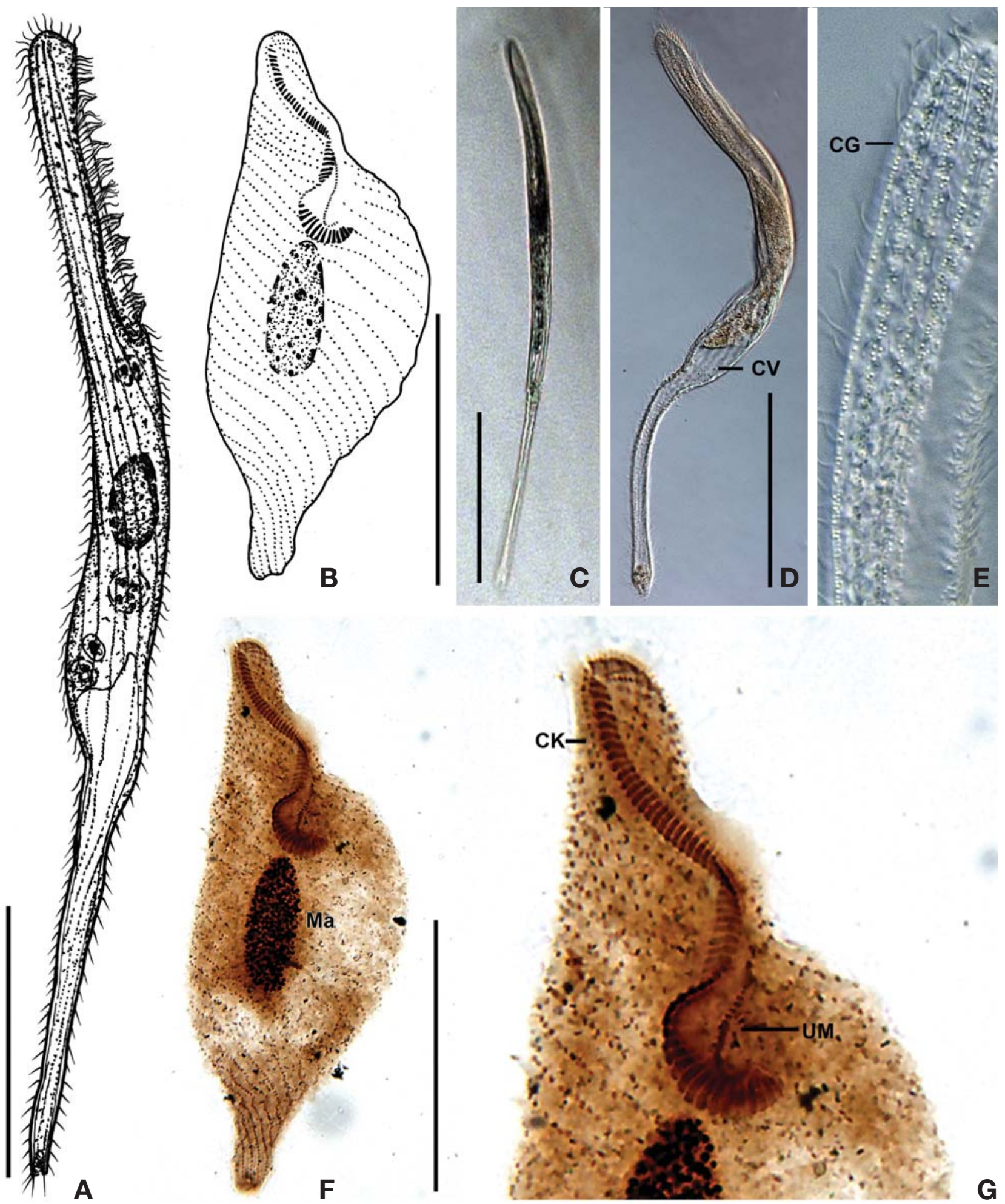

Fig. 1. Spirostomum caudatum from live specimens $(A, C-E)$ and after protargol impregnation (B, F, G). A, C, The typical individuals; $B, F$, Ventral infraciliature; $D$, The twisted body and contractile vacuole; $E$, The cortical granules; G, Buccal field. CG, cortical granule; $\mathrm{CK}$, circumoral kinety; $\mathrm{CV}$, contractile vacuole; $\mathrm{Ma}$, macronucleus; UM, undulating membrane. Scale bars: $\mathrm{A}$, $\mathrm{C}$, $\mathrm{D}=100 \mu \mathrm{m} ; \mathrm{B}, \mathrm{F}=70 \mu \mathrm{m}$. 
Seok Won Jang, Choon Bong Kwon, Mann Kyoon Shin

Table 2. Comparisons of most similar species of genus Spirostomum

\begin{tabular}{|c|c|c|c|c|c|c|c|c|}
\hline Characters & S. caudatum & S. caudatum & S. teres & S. teres & S. teres & S. teres & S. teres & S. yagiui \\
\hline Body length $x$ width (in vivo, $\mu \mathrm{m}$ ) & $400-450 \times 20-30$ & $200-700$ & $240-457 \times 27-38$ & $150-600 \times 20-75$ & $100-400$ & $150-400$ & $300-560$ & $320-480 \times 24-32$ \\
\hline Body length/Body width, ratio & $13-23: 1$ & $10-20: 1$ & $6-13: 1$ & $10-15: 1$ & - & $10-12: 1$ & - & $12-18: 1$ \\
\hline Adoral membranelles, number & $48-56$ & - & $80-92$ & - & ca. 120 & - & - & $130-140$ \\
\hline Macronucleus, shape & Ellipsoid & Ellipsoid & Ellipsoid & Ellipsoid & Ellipsoid & Ellipsoid & Ellipsoid & Rod \\
\hline Micronuclei, number & - & 1 & $2-3$ & $1-2$ & 2 & - & - & $3-7$ \\
\hline Somatic kineties, number & $13-18$ & $28-32$ & $20-30$ & $25-30$ & $12-24$ & - & $20-27$ & ca. 20 \\
\hline $\begin{array}{l}\text { Cortical granules, number of } \\
\text { rows between somatic kineties }\end{array}$ & $2-3$ & ca. 2-3 & $2-3$ & $2-3$ & - & - & - & - \\
\hline Cortical granules, color & Colorless & - & Colorless & Lemon-yellow & - & - & - & - \\
\hline Habitat & Freshwater & Freshwater & Freshwater & Freshwater & Mostly freshwater & $\begin{array}{l}\text { Freshwater or } \\
\text { salt-water }\end{array}$ & Salt-water & Salt-water \\
\hline Data source & Present study & $\begin{array}{l}\text { Foissner et al., } \\
1992\end{array}$ & Present study & $\begin{array}{l}\text { Foissner et al., } \\
1992\end{array}$ & $\begin{array}{l}\text { Dragesco and } \\
\text { Dragesco-Kernéis, } \\
1986\end{array}$ & Kahl, 1932 & $\begin{array}{l}\text { Al-Rasheid, } \\
1999\end{array}$ & Shigenaka, 1959 \\
\hline
\end{tabular}

-, data unavailable.
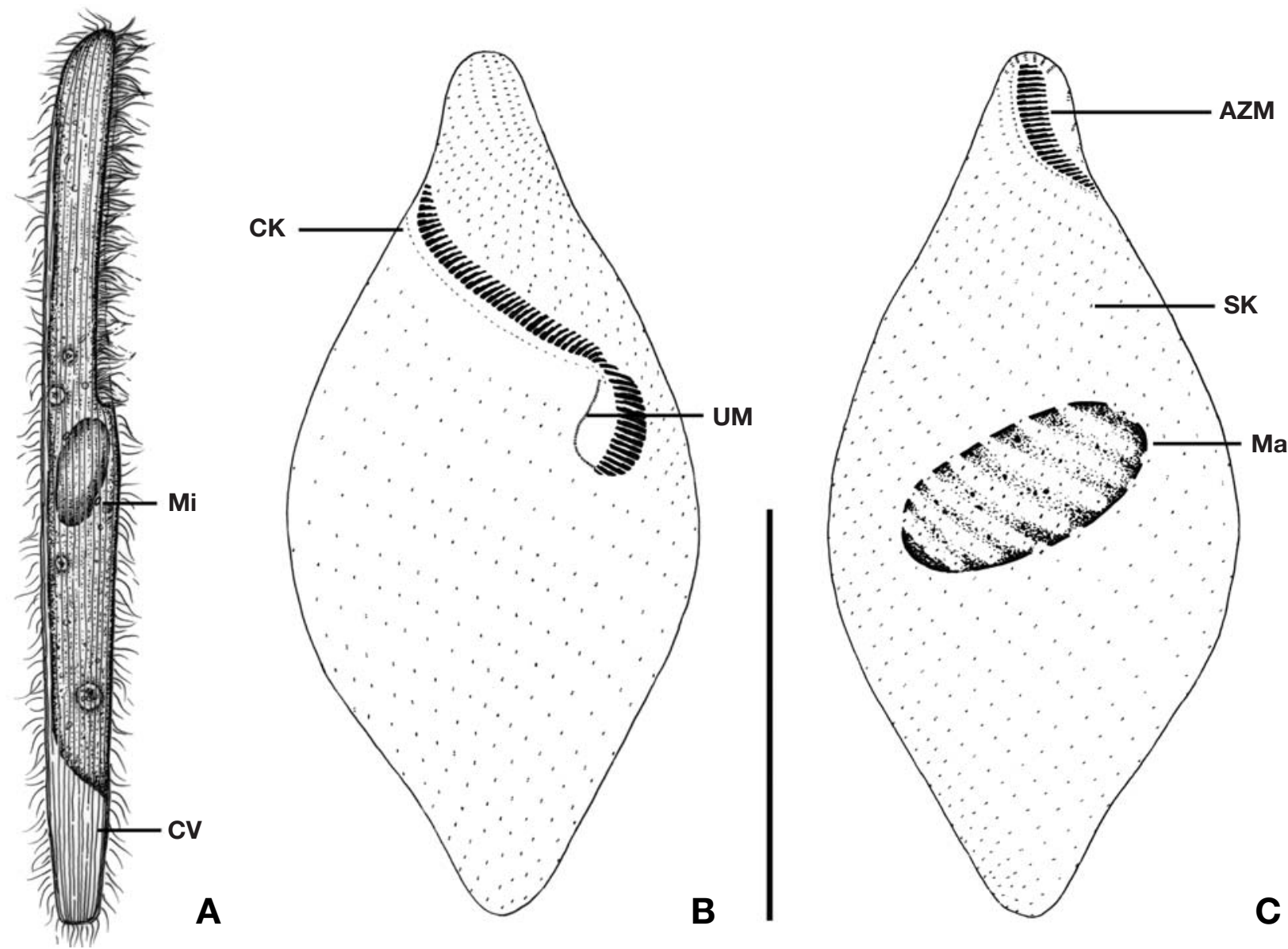

Fig. 2. Spirostomum teres from a live specimen $(A)$ and after protargol impregnation $(B, C)$. $A$, Right side view of a typical individual; $B$, Infraciliature pattern of ventral side; $C$, Infraciliature of dorsal side. AZM, adoral zone of membranelles; CK, circumoral kinety; $\mathrm{CV}$, contractile vacuole; Ma, macronucleus; Mi, micronucleus; SK, somatic kinety; UM, undulating membrane. Scale bars: A-C=100 $\mu \mathrm{m}$. 

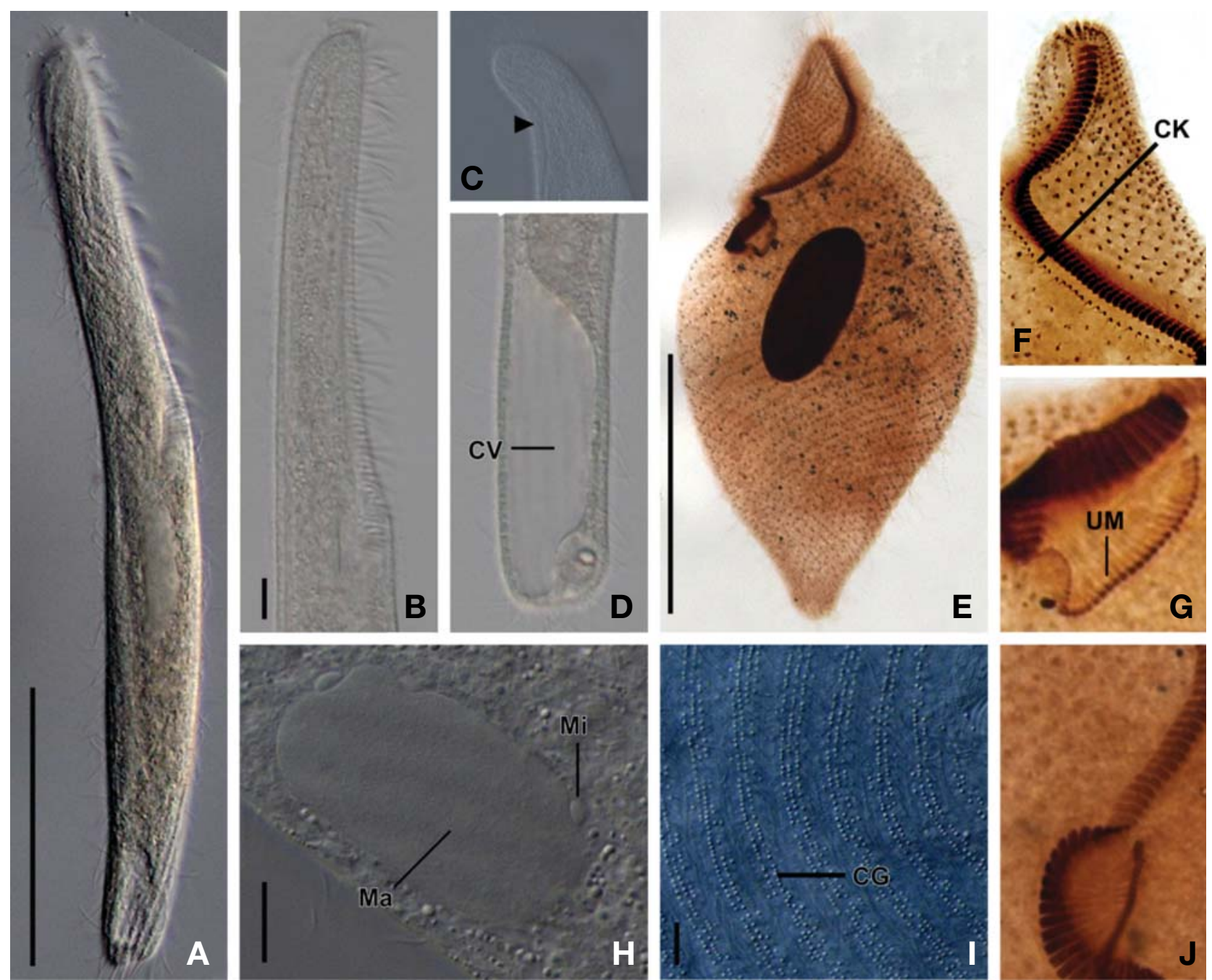

B

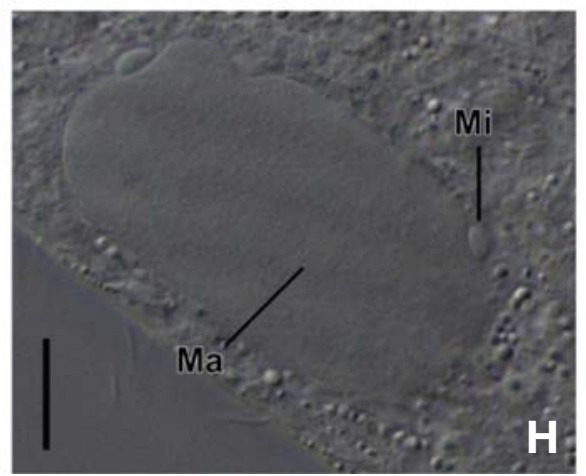

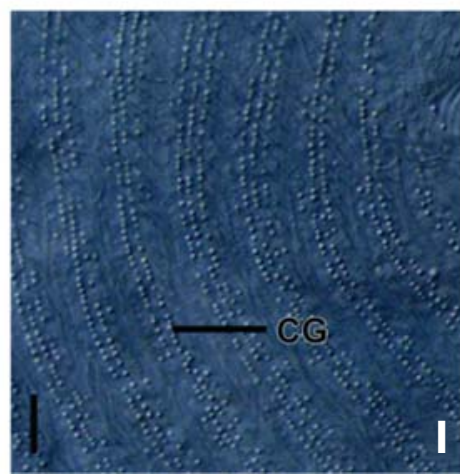
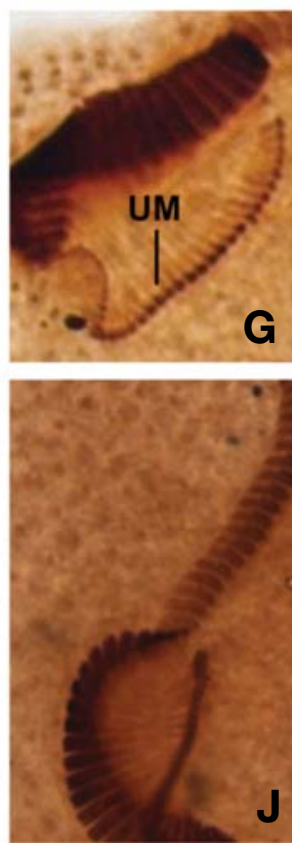

Fig. 3. Spirostomum teres from live specimens (A-D, H, I) and after protargol impregnation (E-G, J). A, Right side view of a typical individual; B, Buccal field in anterior body end; C, Extending canal at anterior body end (arrowhead); $D$, Contractile vacuole in posterior body end; $E$, Infraciliature pattern and nuclear apparatus; F, Circumoral kinety beside AZM; G, Undulating membrane in buccal field; $\mathrm{H}$, Macronucleus and micronucleus; I, Cortical granules pattern between two somatic ciliary rows; J, Twisted adoral zone of membranelles in proximal end of AZM. AZM, adoral zone of membranelles; CG, cortical granule; CK, circumoral kinety; CV, contractile vacuole; Ma, macronucleus; Mi, micronucleus; UM, undulating membrane. Scale bars: $A, E=100 \mu \mathrm{m} ; \mathrm{B}, \mathrm{H}=10 \mu \mathrm{m}$; I=5 $\mu \mathrm{m}$.

tion but arranged spirally when contracted (Fig. 1B, F). Adoral zone occupied $28-35 \%$ of body length (Fig. 1A); adoral zone of membranelles near proximal end twisted one time in impregnated specimens and consisted of 48-56 membranelles (Fig. 1B, F). Undulating membrane consisted of 17-24 dikinetids, near proximal end of adoral zone (Fig. 1G). Circumoral kinety arranged on right side of adoral zone, dikinetids densely in one row (Fig. 1G).

Distribution. Africa, Europe and Asia (Korea [present study]).

Remarks. The Korean population of Spirostomum caudatum is in good agreement with the subsequent redescriptions in body size, tail apparatus, number of somatic ciliary rows, and presence of cortical granules (Foissner et al., 1992) (Table 2).

Spirostomum caudatum (Müller, 1786) is similar to $S$. teres Claparède and Lachmann, 1858, and S. yagiui Shigenaka, 1959 , in respect to its single macronucleus. However, $S$. caudatum and $S$. teres are distinguished by the shape of the posterior end (tail-like vs. blunted), the ratio of the oral length to body length (20-30\% vs. $40-50 \%)$, and the arrangement of the cortical granular rows (irregular vs. regular) (Table 2) (Foissner et al., 1992).

Spirostomum caudatum and S. yagiui are different in the ratio of the oral length to body length (28-35\% vs. about $50 \%)$, 
the number of adoral membranelles (48-56 vs. 130-140), the shape of the macronucleus (ellipsoid vs. rod-shape), the number of micronuclei (1 vs. 3-7) and the habitat (freshwater vs. salt-water) (Table 2) (Shigenaka, 1959; Dragesco and Dragesco-Kernéis, 1986; Foissner et al., 1992).

\section{${ }^{1 *}$ Spirostomum teres Claparède and Lachmann, 1858} (Tables 1, 2, Figs. 2, 3)

Spirostomum teres Claparède and Lachmann, 1858: 233; Stein, 1867: 190; Kahl, 1932: 440; Wang and Nie, 1935: 471; Dragesco and Dragesco-Kernéis, 1986: 378; Foissner et al., 1992: 332; Al-Rasheid, 1999: 130.

Diagnosis. Body size $240-460 \times 30-40 \mu \mathrm{m}$ in vivo; shaped long and slender; macronucleus ellipsoidal; 2-3 micronuclei; cortical granules regularly arranged in 2-3 rows between somatic kineties; 20-30 somatic kineties arranged longitudinally; adoral zone of membranelles covered about 40-50\% of body length with 80-92 adoral membranelles.

Description. Body size $240-460 \times 30-40 \mu \mathrm{m}$, usually about $330 \times 30 \mu \mathrm{m}$ in vivo. Body shaped long and slender with tapered anterior and blunted posterior ends, length to width ratio about $10: 1$ (Figs. 2A, 3A), and body fusiform when contracted. Macronucleus ellipsoidal, located at mid-body, size about $56 \times 24 \mu \mathrm{m}$ in impregnated specimens, $2-3$ ellipsoidal micronuclei, attached to a macronucleus, about $3 \mu \mathrm{m}$ in diameter (Fig. 3E, H). Contractile vacuole located terminally, occupied about 1/4-1/7 of body length with a long canal extending anteriorly (Figs. 2A, 3C, D). Body flexible. Cytoplasm colorless. Cortical granules arranged regularly in 2-3 rows between somatic kineties, colorless, about $0.5 \mu \mathrm{m}$ in diameter in vivo (Fig. 3I).

Movement relatively slow, usually gliding on the bottom. Somatic kineties arranged longitudinally 20-30 in number, but spirally when contracted, consisted of dikinetids, commenced along the apical end to left side of the adoral zone of the membranelles (Figs. 2B, C, 3E), somiatic cilia about $8 \mu \mathrm{m}$ in length. Adoral zone of membranelles occupied $40-50 \%$ of body length (Figs. 2A, 3A), proximal end twisted one time in impregnated specimens (Fig. 3J), and consisted of 80-92 membranelles with each about $10 \mu \mathrm{m}$ in length (Figs. 2B, C, 3B). The undulating membrane consisted of 34-47 dikinetids (Fig. 3G), near the proximal end of the adoral zone, length about $19 \mu \mathrm{m}$. A circumoral kinety arranged at right side of adoral zone, with dikinetids densely in one row (Fig. 3F).

Distribution. Africa, Asia (China, Korea [present study], Saudi Arabia, Turkey), Europe.

Remarks. The Korean population of Spirostomum teres closely resembles the Asian, African and European popula- tions with respect to the ratio of the adoral zone membranelles /body length, the shape of the macronucleus and micronuclei, the number of somatic ciliary rows, and the habitat (Dragesco and Dragesco-Kernéis, 1986; Foissner et al., 1992). However, this Korean population slightly differs from the German population in the color of the cortical granules (lemon-yellow to colorless vs. lemon-yellow), from the African population in the number of adoral membranelles (80-92 vs. about 120) and the number of somatic kineties (20-30 vs. 12-24), and from the Baltic Sea and Arabian Gulf populations (freshwater vs. salt water). The populations of $S$. teres have been recorded in different salinities of habitats so far (Table 2) (Claparède and Lachmann, 1858; Kahl, 1932; Dragesco and Dragesco-Kernéis, 1986; Foissner et al., 1992; Al-Rasheid, 1999; Şenler and Yildiz, 2004). Therefore, it will be needed to disclose the variation caused by environmental gradients using independent criteria like molecular markers or others.

Spirostomum teres and $S$. yagiui are different with respect to the ratio of body length/width (6-13:1 vs. 12-18:1), the number of adoral membranelles (80-92 vs. 130-140), the shape of the macronucleus (ellipsoid vs. rod-shape), the number of micronuclei (2-3 vs. 3-7) and the habitat (freshwater vs. salt-water) (Table 2) (Shigenaka, 1959; Foissner et al., 1992).

\section{ACKNOWLEDGMENTS}

This work was supported by the 2010 Research Fund of University of Ulsan.

\section{REFERENCES}

Al-Rasheid KAS, 1999. Records of marine interstitial Heterotrichida (Ciliata) from the Saudi Arabian Jubail Marine Wildlife Sanctuary in the Arabian Gulf. Arab Gulf Journal of Scientific Research, 17:127-141.

Claparède É, Lachmann J, 1858. Etudes sur les Infusoires et les Rhizopodes. Mémoires de l'Institut National Genevois, 5: 1-260.

Curds CR, Gates MA, Roberts DML, 1983. British and other freshwater ciliated protozoa. part II. Ciliophora: Kinetofragminophora. The Linnean Society of London and The Estuarine and Brackish-Water Sciences Association, Cambridge, pp. 316-317.

Delphy J, 1939. Sur les spirostomes. Archives Néerlandaises de Zoologie, 3:141-145.

Dragesco J, Dragesco-Kernéis A, 1986. Ciliés libres de l'Afrique intertropicale: introduction á la connaissance et á l'étude des ciliés. Faune Tropicale, 26:1-559. 
Foissner W, Berger H, Kohmann F, 1992. Taxonomische und Ökologische Revision der Ciliaten des Saprobiensystems, Band II. Peritrichia, Heterotrichida, Odontostomatida. Informationsberichte des Bayerichen Landesamtes für Wasserwirtschaft, 5/92:1-502.

Kahl A, 1932. Urtiere oder Protozoa. I: Wimpertiere oder Ciliata (Infusoria). 3. Spirotricha. Tierwelt Deutschlands, 25:399650.

Li L, Huang J, Song W, Shin MK, Al-Rasheid KAS, Berger H, 2010. Apogastrostyla rigescens (Kahl, 1932) gen. nov., comb. nov. (Ciliophora, Hypotricha): morphology, notes on cell division, SSU rRNA gene sequence data, and neotypification. Acta Protozoologica, 49:195-212.

Lynn D, 2008. The ciliated protozoa: characterization, classification, and guide to the literature. Springer, New York, pp. 1-605.

Müller OF, 1786. Animalcula infusoria fluviatilia et marina, quae detexit, sytematice descripsit et ad vivum delineari curavit. Mölleri, Havniae et Lipsiae, pp. 1-367.

Penard E, 1922. Etudes sur les infusoires d'eau douce. Georg and Cie, Geneve, pp. 1-331.
Repak AJ, Isquith IR, 1974. The systematics of the genus Spirostomum. Ehrenberg, 1838. Acta Protozoologica, 12:325-333.

Şenler NG, Yildiz I, 2004. Faunistic and morphological studies on ciliates (Protozoa, Ciliophora) from a small pond, with responses of ciliate populations to changing environmental conditions. Turkish Journal of Zoology, 28:245-265.

Shigenaka Y, 1959. A new marine ciliate, Spirostomum yagiui n. sp. Zoological Magazine, 68:368-372.

Stein F, 1867. Der Organismus der Infusionsthiere nach eigenen Forschungen in systematischer Reihenfolge bearbeitet. Bd. II (Allgemeines u. Heterotricha). Wilhelm Engelmann, Leipzig, pp. 1-404.

Wang CC, Nie D, 1935. Report on the rare and new species of fresh-water infusoria, Part II. Sinensia, Shanghai, 6:399-524.

Wilbert N, 1975. Eine verbesserte Technik der Protargolimprägnation für Ciliaten. Mikrokosmos, 64:171-179.

Received September 26, 2011 Revised December 20, 2011 Accepted December 23, 2011 